\title{
The Road to Election Administration Professionalization: Follow the Bottom Line
}

\section{Doug Chapin}

Abstract There is a growing recognition in the field that professionalization of election administration is a vital need for the entire election community. And yet, despite ever-increasing numbers of educational programs and opportunities - not to mention evidence that such programs lead to better outcomes for voters-states have been slow to require professional training for their election officials. One reason may be the lack of a connection between professionalization and states' bottom lines: that is, a linkage between an increase in training and cost-related election outcomes like reducing errors, more effective spending, and increased cost efficiency. Accordingly, the field needs to find a way to gather information on election costs and link it to the presence or absence of professional election administration training. Quite simply, professionalization advocates need to help policymakers "follow the money."

Keywords Election administration - Professionalization $\bullet$ Education and training $\bullet$ State policy $\bullet$ Election costs $\bullet$ Effectiveness $\bullet$ Efficiency

D. Chapin $(\bowtie)$

Fors Marsh Group, Arlington, VA, USA

e-mail: DChapin@forsmarshgroup.com

(C) The Author(s) 2019

M. Brown et al. (eds.), The Future of Election Administration, Elections, Voting, Technology, https://doi.org/10.1007/978-3-030-18541-1_20 
One of the most encouraging aspects of America's growing focus on the field of election administration has been the recognition that better training and education for election professionals is a vital component of the long-term health of the nation's democracy.

Indeed, the 2014 report of the Presidential Commission on Election Administration included this passage regarding professionalization:

[T] he Commission found general agreement that election administration is public administration. That means that in every respect possible, the responsible department or agency in every state should have on staff individuals who are chosen and serve solely on the basis of their experience and expertise. The Commission notes that this is often the case in departments across the country, and it is a model to which all jurisdictions should aspire.

Elected officials are well-served having professional support, and it would also bolster the voting public's confidence in the voting process. Professionalism in administration assumes particular importance in a field characterized by scarcity of resources and increased public demand for a high quality of administration with keen political sensitivities.

It is evident to the Commission that the core competencies required of today's election administrator are different from those in the past. The last decade's heightened demand for more professional administration of elections and modernization of the process demonstrates that there is an increasing need for technology acumen, public relations skills, and data savvy.

Indeed, the Commission would go further and urge the integration of election administration in university curriculums of public administration. For the most part, election officials now migrate into their positions from other areas of government or political party service. Once there, certification and training programs run by Secretaries of State, state associations of clerks, or national organizations, such as the Election Center and the [International Association of Government Officials], become the forums for professional development. It is time that election administration is also counted among those fields for which graduate training in a professional school can constitute preparation for a career (Presidential Commission on Election Administration 2014, 18-19).

Fortunately, those existing training programs are supplemented now by masters- and undergraduate-level education at Auburn University ${ }^{1}$ and

\footnotetext{
${ }^{1}$ http://bulletin.auburn.edu/thegraduateschool/graduatedegreesoffered/publicadministrationandpublicpolicympaphd_major/electionadmin_cert/.
} 
the University of Minnesota. ${ }^{2}$ The national accrediting body for graduate education in public service, the National Association of Schools of Public Administration and Affairs (NASPAA), has initiated efforts to pool common resources from these programs to make them available for graduate education at other institutional members that focus on public administration, public affairs, and/or public policy. ${ }^{3}$ These efforts are reaching an ever-increasing number of students and election officials at every level of experience and in every community.

To be sure, the growing supply of educational opportunities is a huge plus for the field, and as such appears to be associated not only with a strong uptick in state training programs but also with overall improvements in both voter participation and the quality of service. ${ }^{4}$

While this Field of Dreams approach ("build it, and they will come") is necessary, it is insufficient to ensure long-term professionalization of election administration. Rather, as I'll discuss below, the better approach is to follow the advice of "Deep Throat" in All the President's Men: "follow the money."

Many of the challenges facing professionalization-indeed, all of election administration-are tied to scarcity of resources. Despite some injections of federal dollars via the Help America Vote Act $^{5}$ and the recent election cybersecurity funds in the FY2019 federal omnibus, ${ }^{6}$ states (and more often localities) are left on their own to fund voting technology purchases and other aspects of election administration.

Because of this, current professionalization efforts are driven by availability of resources in specific communities or at different levels of experience in the field. In other words, current spending and investment in professional education and training tends to come from jurisdictions with larger budgets - and thus more disposable funds - or more from senior administrators who view the courses as a capstone for years of experience as opposed to a gateway into, or ladder up, the field.

One key reason for the lack of greater public-sector investment in professional education and training is the absence of any particular financial

\footnotetext{
${ }^{2}$ https://www.hhh.umn.edu/certificate-programs/certificate-election-administration.

${ }^{3}$ http://www.naspaa.org/students/InternshipSum17_ElectionAdministration.pdf.

${ }^{4}$ https://www.dropbox.com/s/l15bupsuw9k76x7/BrownHaleESRA2017rev072417. pdf?dl=0.

${ }^{5}$ PL 105-272 (2002).

${ }^{6} \mathrm{PL} 115-141$ see also Chapin, http:/ / editions.lib.umn.edu/electionacademy/2018/03/22/ omnibus-budget-to-include-380m-for-election-security/.
} 
incentive for governments to fund it-or for administrators to enroll. For the most part, election administration is unlike other disciplines in the public administration field, in which professionals either obtain additional credentials for additional pay/status or are required to do so as a condition of keeping their jobs. ${ }^{7}$ Louisiana is an outlier in that it offers a financial incentive for election officials to obtain and maintain professional certification through the national certification program developed and offered by the Election Center in partnership with Auburn University.

Consequently, states and localities and their election officials end up in a "chicken and egg" situation regarding professional training. Governments do not want to fund professional training in election administration unless they can see benefits in the conduct of elections. In addition, election officials do not want to enroll unless they get some kind of benefit for participating.

For this reason, the next step toward widespread professionalization of the field-which I define as nationwide state and/or local training requirements supported by salary and promotion benefits for administrators-is to demonstrate the fiscal benefits that accrue in addition to the civic benefits of better training and education of election professionals. In the long run, that probably means demonstrating the positive effect of professional education on most if not all of the following: (1) money spent (in aggregate and per voter) on election administration-both overall ("cost of elections") and for individual elections ("costs of an election"); (2) more efficient and cost-effective technology investments, including optimal balance of in-house and outsourced work; (3) decreases in "fix-it" costs like change orders, temporary labor, and the like; and (4) reduction in postelection litigation and other challenges to election outcomes.

By linking these outcomes to increased salaries, promotion, and training for election administration, policymakers can be assured that education and training is adding value to the election process-and is thus worth committing taxpayer dollars to support. While initially this link may only trigger investments by jurisdictions with the funds to cover the costs, over time the growing evidence base-and the decrease in per-student costs as enrollments increase-should attract new communities into the fold.

But in order to make this work, the field needs better data on what it costs to run elections in this country. Election costs are the "white whale" of election administration-incredibly valuable information that would

\footnotetext{
${ }^{7}$ See, for example, https://coopercenter.org/services/government-training.
} 
help make sense of so many different aspects of the nation's election system, but elusive because of the decentralized nature of the nation's election system. I often joke that the nation has a uniform election system in that everybody does things their own way that is intensified in the costs sphere, where state-, local-, and community-level variation in funding and accounting for election spending result in wildly divergent systems of tracking and reporting.

Fortunately, we are starting to make headway in thinking throughand even collecting! — cost data from election officials nationwide. A recent paper by Mohr, Kropf, Pope, Shepherd, and Esterle (2018) illuminates a new way to categorize and analyze election cost data.

$[\mathrm{W}] \mathrm{e}$ discuss the measurement and conceptualization of the costs involved in elections, and the ways that this cost can be operationalized. By this, we mean not just the direct costs of one particular election, but also the costs for personnel, voter registration work, other "between election" costs. Although cost data can come from various sources-including budgets, audited financial statements, and cost accounting-we ultimately focused our research and discussion of election costs on the financial data provided by [annual financial report] expenditures (Mohr et al. 2018, p. 1).

By identifying distinctions between the cost of individual elections and an overall cost of elections, this approach suggests a way to capture the effect of greater professionalization on total costs as well as track it from election to election.

For this reason, I believe it is incumbent upon election officials nationwide - and perhaps more importantly, in their best interest - to cooperate with efforts to improve election cost reporting as the best possible way to bring greater professionalization to the field. By improving cost reporting, we can see what the greatest cost drivers are in elections and make meaningful comparisons between and across jurisdictions. Armed with this information, election organizations and universities can collaborate on designing and fielding courses aimed at improving performance in these high-leverage areas as well as overall. Researchers can assess the influence that training has on election costs. State and local governments can use these data to create financial and job incentives for election officials to take the training. Well-trained professional election officials can further improve output and outcome data. Lather, rinse, repeat. 
Obtaining these data can happen in a number of different ways, but the two most promising are for election jurisdictions to (a) be more forthcoming with financial data on elections when solicited by researchers, and (b) adopt and use a standard "chart of accounts" for election spending. This latter approach may grow in popularity as the push to create and implement common data standards gains traction in the election administration field. ${ }^{8}$

In conclusion, then, I believe the way forward for greater professionalization of election administration is to continue to maintain the emphasis on its civic benefits-higher turnout, greater confidence, and so on-while layering on a new focus on fiscal benefits derived from both better cost accounting and an increasingly evidence-based focus on the impact of training on election outcomes other than election returns.

Just as campaigns have discovered the power of personalizing political messages- "here's how this election affects YOU"-so must the election profession (and the academics who love them) make the case to policymakers that better education and training are worth paying for because they not only improve the experience but benefit the bottom line.

\section{REFERENCE}

Mohr, Zachary, Martha Kropf, JoEllen Pope, Mary Jo Shepherd, and Madison Esterle. 2018. Election Administration Spending in Local Election Jurisdictions: Results from a Nationwide Data Collection Project. Paper presented at the 2018 Election Sciences, Reform and Administration Conference, Madison, Wisconsin, 1-32.

\footnotetext{
${ }^{8}$ http://editions.lib.umn.edu/electionacademy/2018/03/23/katy-owens-hubler-inelectionlineweekly-on-common-data-format/.
} 
Open Access This chapter is licensed under the terms of the Creative Commons Attribution 4.0 International License (http://creativecommons.org/licenses/ by $/ 4.0 /$ ), which permits use, sharing, adaptation, distribution and reproduction in any medium or format, as long as you give appropriate credit to the original author(s) and the source, provide a link to the Creative Commons licence and indicate if changes were made.

The images or other third party material in this chapter are included in the chapter's Creative Commons licence, unless indicated otherwise in a credit line to the material. If material is not included in the chapter's Creative Commons licence and your intended use is not permitted by statutory regulation or exceeds the permitted use, you will need to obtain permission directly from the copyright holder. 